\title{
Prevalence and Factors Associated with Bullying Phenomenon Among Pre-Adolescents Attending First-Grade Secondary Schools of Palermo, Italy, and a Comparative Systematic Literature Review.
}

Claudio Costantino ( $\square$ claudio.costantino01@unipa.it ) Universita degli Studi di Palermo https://orcid.org/0000-0002-3397-7331

Walter Mazzucco

University of Palermo: Universita degli Studi di Palermo

Francesco Scarpitta

University of Palermo: Universita degli Studi di Palermo

Gianmarco Ventura

University of Palermo: Universita degli Studi di Palermo

Claudia Marotta

University of Palermo: Universita degli Studi di Palermo

Stefania Enza Bono

University of Palermo: Universita degli Studi di Palermo

Evelina Arcidiacono

Regional Sicilian Education Authority

Maurizio Gentile

Regional Sicilian Education Authority

Pierfrancesco Sannasardo

Local Health Authority of Palermo

Carlo Roberto Gambino

Local Health Authority of Palermo

Claudia Emilia Sannasardo

University of Palermo: Universita degli Studi di Palermo

Carlotta Vella

University of Palermo: Universita degli Studi di Palermo

Francesco Vitale

University of Palermo: Universita degli Studi di Palermo

Alessandra Casuccio

University of Palermo: Universita degli Studi di Palermo

Vincenzo Restivo

University of Palermo: Universita degli Studi di Palermo 


\section{Research}

Keywords: bullying, systematic literature review, bullying prevalence, observers, pre-adolescents

Posted Date: September 20th, 2021

DOI: https://doi.org/10.21203/rs.3.rs-885695/v1

License: (c) (1) This work is licensed under a Creative Commons Attribution 4.0 International License. Read Full License

Version of Record: A version of this preprint was published at Italian Journal of Pediatrics on April 4th, 2022. See the published version at https://doi.org/10.1186/s13052-022-01245-2. 


\section{Abstract}

Background: Bullying is recognized as one of the most significant social and health problems in the school environment for children and adolescents. In Italy, bullying involved 2 in 10 kids between 11-17 years that referred to have been bullied two or more times in a month. In Sicily, the estimated prevalence of children aged 11 to 15 that suffered at least one act of bullying in the last two months was $14 \%$ in 2011.

Methods: A questionnaire consisting of 30 items investigating physical, verbal and indirect bullying, observers of bullying, resiliency, and prosociality was administered to preadolescents of ten first-grade secondary schools within the Palermo Province in order to analyze prevalence and factors associated with bullying phenomenon. Also, a systematic literature review (SLR) analyzing manuscripts that reported prevalence of the bullying phenomenon worldwide was conducted.

Results: Survey. a total of 867 students, belonging to 35 second and 31 third classes of ten different schools in Palermo, Italy, were recruited in the survey. The values of physical bullying are included between the $4 \%$ of the single question method and the almost forty percent detected by the score of 7 method. Verbal bullying oscillates between $15.9 \%$ and $66.3 \%$. Observers average values varies from $15.8 \%$ to $47.5 \%$.

$S L R$ : the estimated prevalence showed a considerable fluctuation. The occurrence of the bullying phenomenon was low in some Northern European countries, while in Anglo-Saxon countries it affected over a quarter of the middle school student population ( $28 \%$ in Maryland, USA and $21 \%$ in the UK).

Conclusions The prevalence of the bullying phenomenon recorded by this survey with the three different methods used is similar to observations in international literature. In the Sicilian context, a higher prevalence of bullying phenomena was observed in pre-adolescents attending major classes and in schools with lower socio-economic index. Though it remains difficult to obtain univocal data that clarifies the prevalence of different type of bullying, the continuous investigation of prevalence and factors associated with the phenomenon is a necessary starting point to introduce interventions and preventive measures in Public Health programs.

\section{Background}

Bullying is recognized worldwide as one of the most significant social and health problems in the school environment for children and adolescents [1]. In recent decades, bullying has gained a growing interest in public health, catalyzing many efforts both in research and in action [2,3]. Currently, this marked interest on the topic has not been followed by a universally recognized agreement on their definition.

Taking into account the local peculiarities of bullying, the global burden of the phenomenon is hard to estimate [4]. 
In the early nineties of the last century, based mainly on the works of Olweus [5-8], and in the first decade of this century, referring to the works of Farrington [9-12], a more scientific approach in the evaluation of bullying emerged.

In particular, the most punctual and universally accepted definition of bullying, that identified intentionality, duration over time and asymmetry in the relationship as the main elements of bullying phenomenon, was attributed to the work of Farrington et al [9].

On the other hand, the implementation of surveys that allowed a detailed analysis of the phenomenology of bullying and the characteristics of its main actors (bullies, victims and observers) was due to the Norwegian school of Olweus and colleagues [5]. Victims can present the most disparate characteristics of "diversity": ethnicity, obesity, sexual habits or, more generally, elements that characterize only a small minority of subjects belonging to a group [13-14]. More recently, the "cyber-bullying" phenomena has spread, consisting of episodes of bullying perpetrated through electronic tools (computers, smartphones) and favored by the growing access to the internet even among young and very young people $[12,15-16]$.

In Italy, bullying involved 2 in 10 kids between 11-17 years that referred to have been bullied two or more times in a month [17].

Moreover, in Sicily, the first Italian region by territorial extension and the fourth most populous, the estimated prevalence of children aged 11 to 15 that suffered at least one act of bullying in the last two months was $14 \%$ in 2011 [18].

Prevalence data and factors associated with bullying phenomenon obtained in a survey conducted by the Bullying in Sicilian Schools (B.I.A.S) working group among students attending first-grade secondary school in the metropolitan area of Palermo, the largest city in Sicily (Italy) were investigated.

Moreover, we aimed to analyze the prevalence of bullying that has emerged in other studies conducted by groups and by national or supranational institutions, also to compare different strategies used in the detection of bullying phenomena.

\section{Materials And Methods}

Questionnaire. During the school year 2017/18 the BIAS (Bullying in Sicilian Schools) working group carried out a survey among students attending ten school institutions in the City of Palermo, Sicily [19], in order to estimate the prevalence of bullying in the pre-adolescent age group.

The City of Palermo is the most populous Sicilian city. The study population included all the 22,455 school-aged children, attending one of the 58 secondary first-grade schools of Palermo, Italy. A two-stage cluster sampling process was performed. Based on the $14 \%$ bullying among Sicilian students (prevalence), with a $99.9 \%$ desired level of significance and an average number of 20 students per class, the minimum study population needed was 555 students. Schools were considered as primary units of the sampling, while classes as secondary units. 
The schools, based on sociodemographic criteria, were categorized into three levels - high (A), intermediate (B), and low (C) - in accordance with the neighborhood socioeconomic index (SEI), based on the logarithm of the median household income, the proportion of adults aged 25 years or older with a high school diploma or college degree, and the proportion of people employed. Then, at least three schools and a minimum of 4 classes in each school from each level were selected.

After obtaining written consent from their parents, an anonymous questionnaire was self-administered by the students from December 2017 to February 2018, using an open access web-based platform (Google $®$ Forms) to evaluate the baseline prevalence of bullying from the students' perspective. The questionnaire consisted of an introductive section on socio-demographic data (gender, age, nationality, school institution and class attended), followed by 30 items investigating the six main areas of practical interest and research on bullying: 1) physical bullying, 2) verbal bullying, 3) indirect bullying, 4) observers, 5) resiliency, and 6) prosociality (five questions for each area) [19-20].

All 30 questions are based on a Likert Scale from 1 to 5 as follows [19]:
1. Never
2. Rarely (only once or twice)
3. Occasionally (three to six times)
4. Often (about once a week)
5. Very often (several times a week)

An open-ended section to freely express thoughts about 1 ) the content of the questionnaire and 2) bullying in general was included at the end of the questionnaire. For each answer, a score between one (never) and five (very often) was assigned.

The score was then used to detect the baseline level of bullying with the following three methods: 1 . Sentinel question method, where the presence or absence of bullying was investigated through "yes" answers to the most significant questions in an area. The responses very often, often, and occasionally were considered affirmative answers. 2 . The five-question method, which considered bullying to be present whenever the student answers yes (i.e. occasionally, often, or very often) to at least one of the items in the survey area. 3. The score of seven method, where the answers to each question were scored and added and the presence or absence of bullying was then determined, while the value of seven was considered the cutoff (i.e. the respondent could answer occasionally to at least one of the questions in an area).

The sentinel questions for the six areas were: 1. "Since I started first-grade secondary school, another boy or girl has hurt me alongside other boys or girls" (physical bullying); 2. "'Since I started first-grade secondary school, another boy or girl has insulted me (even on online platforms)" (Verbal bullying); 3. "Since I started first-grade secondary school, another boy or girl has turned another boys or girls against me (even on online platforms)" (Indirect bullying); 4. "Since I started first-grade secondary school, I saw a 
friend insulted by another boys or girl (even on online platforms), but I preferred to mind my own business" (Observers); 5. "Since I started first-grade secondary school, if I am bullied, I rebel " (Resiliency); 6. "Since I started first-grade secondary school, I was bullied and I talked about what happened with the teacher (Prosociality).

Cronbach's alpha was carried out in order to evaluate the estimated reliability of the questionnaire.

In this study the Cronbach's alpha for physical, verbal, indirect bullying, and also for observers, prosociality and resiliency were calculated and corresponded to $.86, .84, .86, .88, .87$ and .86 with an adequate reliability of the test.

Data obtained were exported into an electronic database created by Excel 16.0 software and analyzed using STATA14® software.

Systematic literature review (SLR). A systematic literature research of the main manuscript that reported the prevalence of the bullying phenomenon published between January 2011 and February 2019 was conducted. The research was conducted on electronic databases including PubMed/MEDLINE, SCOPUS, EMBASE, ISI Web of Science, Google Scholar as well as the grey literature. In details, the following search terms were used: ((bullying AND prevalence)) AND ("2011/01/01"[Date - Create] : "2019/02/28"[Date Create]))

Inclusion criteria:

- Type of publication: original scientific articles or reports;

- Publication of the source from January 1, 2011 to February 28, 2019;

- Language of publication: English;

- Area of publication: worldwide;

- Full text available online.

The research was set to achieve a representativeness of all continents, focusing mainly on the European one.

Exclusion criteria:

- Publication of the paper or report prior to January 1, 2011 (with the exception of works concerning countries for which no more updated data were present);

- Reviews and meta-analysis; works not published in English;

- Inclusion of subjects under study aged less than ten years or over seventeen;

- Studies still in progress as of February 28, 2019;

- Lack of the definitive prevalence data specified in the results;

- Lack of a defined and explicit protocol describing how the prevalence data had been obtained; 
- Lack of representativeness of the subjects in relation to the demographic characteristics of the study population and the territory to which they belong;

- Tangible lack of relevance of the papers / reports with the aim of this study, after reading their abstracts.

The working group may have further applied additional exclusion criteria not previously considered during the reading of full-text contributions. The results were then extrapolated from the articles and reports found, summarized and, finally, organized in a comparison table with the results of this survey.

Statistical analysis. All categorical variables were reported as absolute and relative frequencies (percentages). Chi-squared tests (with Fisher's correction where appropriate) were used to compare categorical variables and comparative analyses performed by school socioeconomic index. Quantitative variables were normally distributed and summarized as means with their standard deviations.

Differences in means were compared with the Student t-test for a paired sample. All the variables found to have an association with bullying phenomenon $\leq 0.20$ (any form of physical, verbal, indirect bullying or observer role evidenced with the five-question method) in the univariate analysis were included in a backward stepwise logistic-regression model. Adjusted OR (adj-OR) with $95 \%$ confidence intervals (95\% Cls) were calculated for the variables retained in the final model. The significance level fixed for the whole analysis was 0.05 , two-tailed.

\section{Results}

\subsection{Survey results}

A total of 867 students, belonging to 35 second and 31 third classes of ten different schools in Palermo, Italy, were recruited in the survey. Among students, $51 \%(n=444)$ were females and $49 \%(n=423)$ were males. Only $2 \%(n=20)$ of respondents were of foreign nationality. The average age of the entire sample was 12.3 years $( \pm S D=1.23)$ (data not shown).

Table 1 shows the prevalence of the main types of bullying investigated (physical, verbal and indirect), according to the three used methods of analysis.

The values of physical bullying are included between the $4 \%$ of the single question method and the almost forty percent detected by the score of 7 method. Verbal bullying oscillates between $15.9 \%$ and $66.3 \%$. Observers average values varies from $15.8-47.5 \%$. 
Table 1

Prevalence of bullying by comparing the three methods selected and average values of bullying phenomenon in the study population $(n=867)$.

\begin{tabular}{|c|c|c|}
\hline & Methods & Prevalence (\%) \\
\hline \multirow[t]{3}{*}{ Physical } & Single question & $35(4)$ \\
\hline & Five questions & $241(27.8)$ \\
\hline & Score of 7 & $346(39.9)$ \\
\hline \multirow[t]{3}{*}{ Verbal } & Single question & $138(15.9)$ \\
\hline & Five questions & $370(42.7)$ \\
\hline & Score of 7 & $575(66.3)$ \\
\hline \multirow[t]{3}{*}{ Indirect } & Single question & $105(12.1)$ \\
\hline & Five questions & $295(34)$ \\
\hline & Score of 7 & $431(49.8)$ \\
\hline \multirow[t]{3}{*}{ Observer } & Single question & $137(15.8)$ \\
\hline & Five questions & $288(33.2)$ \\
\hline & Score of 7 & $412(47.5)$ \\
\hline \multirow[t]{3}{*}{ Average Bullying values } & Single question & $(11.8)$ \\
\hline & Five questions & (34.3) \\
\hline & Score of 7 & (50.9) \\
\hline
\end{tabular}

Finally, the indirect one increases from the $12.1 \%$ of the single question to the $49.8 \%$ derived from the score of 7 methods. Finally, the average value of bullying obtained considering the mean prevalence of physical, verbal, indirect bullying and observers was $11.8 \%$ for the single question method, $34.3 \%$ for the five questions method, and $50.9 \%$ with the score of 7 method.

In Table 2 data on attitudes and roles of the actors involved in bullying episodes are shown. Attitude of prosociality started from a minimum of $12.5 \%$ (single question) up to $89.2 \%$ (score of 7 ). Resiliency showed a range of about thirty percentage points (from $37.8-68 \%$ ). 
Table 2

Prevalence anti-bullying attitudes and roles by comparing the three methods selected among the study population $(n=867)$.

\begin{tabular}{|lll|}
\hline \multirow{3}{*}{ Prosociality } & Methods & Prevalence (\%) \\
\cline { 2 - 3 } & Single question & $108(12.5)$ \\
\cline { 2 - 3 } & Five questions & $709(81.8)$ \\
\cline { 2 - 3 } Resiliency & Score of 7 & $773(89.2)$ \\
\cline { 2 - 3 } & Single question & $328(37.8)$ \\
\cline { 2 - 3 } & Five questions & $479(55.2)$ \\
\cline { 2 - 3 } & Score of 7 & $590(68.0)$ \\
\hline
\end{tabular}

Table 3 reports the univariate (Crude OR) and multivariate (Adj-OR) analysis between the bullying phenomenon prevalence (physical, verbal, indirect bullying or observers) correlated with sociodemographic factors (gender, class, nationality and school SEI) of the population in study.

The bullying phenomena resulted more frequently in higher school classes, in particular (third vs second year of study course). A significant higher prevalence of bullying was observed in students attending third level classes (OR 1.76; $\mathrm{Cl} 95 \%$ 1.21-2.58; $p$-value < 0.01) and in students attending schools with lower socio-economic index (OR 1.21; IC 95\% 1.06-1.53; p-value< 0.05 ).

Table 3

Univariate (Crude-OR) and multivariate (Adjusted-OR) analysis of factors associated with bullying phenomenon (average physical, verbal, indirect bullying or observer prevalence with the five-question method) in the study population $(n=867)$.

\section{Factors associated with bullying phenomenon}

\begin{tabular}{|c|c|c|c|c|c|c|}
\hline & $\begin{array}{l}\text { Crude- } \\
\text { OR }\end{array}$ & $\mathrm{Cl} 95 \%$ & $\begin{array}{l}\mathrm{p}- \\
\text { value }\end{array}$ & $\begin{array}{l}\text { Adj- } \\
\text { OR }\end{array}$ & $\mathrm{Cl} 95 \%$ & $\begin{array}{l}\mathrm{p} \text { - } \\
\text { value }\end{array}$ \\
\hline Age (for each additional year) & 0.98 & $\begin{array}{l}0.68- \\
1.41\end{array}$ & 0.18 & 0.96 & $\begin{array}{l}0.76- \\
1.21\end{array}$ & 0.73 \\
\hline Gender (male vs female) & 1.12 & $\begin{array}{l}0.65- \\
1.89\end{array}$ & 0.36 & & & \\
\hline School year (Third Vs Second) & 1.89 & $\begin{array}{l}1.42- \\
2.87\end{array}$ & $\begin{array}{l}< \\
0.01\end{array}$ & 1.76 & $\begin{array}{l}1.21- \\
2.58\end{array}$ & $\begin{array}{l}< \\
0.01\end{array}$ \\
\hline Nationality (Foreign vs Italian) & 1.56 & $\begin{array}{l}0.52- \\
2.34\end{array}$ & 0.55 & & & \\
\hline $\begin{array}{l}\text { School SEl (for decreasing socio- } \\
\text { economic index) }\end{array}$ & 1.24 & $\begin{array}{l}1.12- \\
1.69\end{array}$ & $<.05$ & 1.21 & $\begin{array}{l}1.06- \\
1.53\end{array}$ & $<.05$ \\
\hline
\end{tabular}




\subsection{Systematic literature review (SLR)}

A total of over 1,400 scientific articles emerged from a first phase of bibliographic research. In addition, national, continental and global data-based reports, published on institutional websites, were considered. During the screening phase, 1,256 manuscripts remained after removal of duplicates and manuscripts written in languages other than English (Fig. 1). During the eligibility phase, 1,242 articles were removed due to exclusion criteria (Fig. 1).

Specifically, during this phase, one manuscript was added and two were excluded from the review after collegial discussion among the working group. At the end of the process, thirteen studies were selected for comparison (Fig. 1).

The eligible manuscripts (Table 4) were from four different continents (America, Asia, Europe and Oceania). As far as the African continent is concerned, no surveys referring to individual states have been found, but only data limited to individual urban areas or aggregate data of supranational reports. The selection of the article covers a period of eight years, from 2011 to 2019 [21-33]. After a collegial discussion involving the entire working group, we decided to include two works concerning Tajikistan and the Republic of Macedonia, respectively, as the last ones available, in a chronological sense, to investigate the phenomenon of bullying in these specific areas. Also, two surveys included first (Boston College, 2011, and London School of Economics and Political Science, 2014) were subsequently excluded after a revaluation by the working group considering them inhomogeneous toward guaranteeing comparability with the others selected studies.

The evaluation of bullying prevalence was conducted among the pre-adolescents and the adolescents attending first-grade secondary schools through self-compiled questionnaires, in paper or online anonymous forms.

None of the selected works included a face-to-face interview conducted by an adult. With regard to the number of questions, they varied from a single question, included in more structured works, to dedicated questionnaires consisting of several questions.

The time window investigated ranged from thirty days prior to completing the questionnaire (two studies), up to two, six or twelve months before (one study). Other works analyzed the prevalence of bullying during the whole school year, regardless of the number of months considered.

Four of the European publications reported data extrapolated from the last Health Behavior in Schoolaged Children (HBSC) survey. At least three of the selected works explicitly investigated the area of electronically perpetrated bullying (cyber-bullying). Nearly all the studies analyzed the relation between the victim and the bully.

The sample size of the enrolled students was extremely variable in the different surveys, ranging from a few hundred to over two hundred thousand children involved. 
Even the estimated prevalence showed a considerable fluctuation: the occurrence of the bullying phenomenon was low in some Northern European countries (for example, Iceland and Sweden, which reported prevalence between 0.3 and 5.7\%) [21,22], while in Anglo-Saxon countries it affected over a quarter of the middle school student population (28\% in Maryland, USA and $21 \%$ in the UK) $[25-27,30]$. Finally, among the selected studies, there was an outlier value of close to a third of the interviewees (29\% declared to have witnessed bullying attitudes) recorded in China [24]. 
Table 4

General characteristics and prevalence of bullying observed in the thirteen selected studies during screening and eligibility processes of the SLR.

\begin{tabular}{|c|c|c|c|c|c|c|}
\hline Country & Year & Authors & Title & Detection mode & $\begin{array}{l}\text { Sample } \\
\text { and age } \\
\text { class }\end{array}$ & $\begin{array}{l}\text { Bullying } \\
\text { Prevalence }\end{array}$ \\
\hline \multirow[t]{9}{*}{$\begin{array}{l}\text { Denmark, } \\
\text { Finland, } \\
\text { Greenland, } \\
\text { Iceland, } \\
\text { Norway, } \\
\text { Sweden }\end{array}$} & \multirow[t]{9}{*}{2019} & \multirow[t]{9}{*}{$\begin{array}{l}\text { Amarsson } \\
\text { et al. } \\
{[21]}\end{array}$} & \multirow[t]{9}{*}{$\begin{array}{l}\text { Cyberbullying } \\
\text { and traditional } \\
\text { bullying } \\
\text { among Nordic } \\
\text { adolescents } \\
\text { and their } \\
\text { impact on life } \\
\text { satisfaction }\end{array}$} & \multirow[t]{9}{*}{$\begin{array}{l}\text { HBSC } \\
2013 / 2014 \\
\text { (single item: } \\
\text { "How often } \\
\text { have you been } \\
\text { bullied at } \\
\text { school in the } \\
\text { past couple of } \\
\text { months?") }\end{array}$} & \multirow[t]{9}{*}{$\begin{array}{l}32,210 \\
\text { students } \\
(11,13 \\
\text { and } 15 \\
\text { y.o.) }\end{array}$} & $\begin{array}{l}\text { Norwegian } \\
\text { Males: 2.7- } \\
\text { 7.8\% } \\
\text { Females: } \\
\text { 3.1-5.2\% } \\
\text { Danish M: } \\
2.7-8.0 \%\end{array}$ \\
\hline & & & & & & $\begin{array}{l}\text { Finnish M: } \\
6.4-12.6 \%\end{array}$ \\
\hline & & & & & & $\begin{array}{l}\text { F: } 6.5-8.2 \% \\
\text { Greenlander }\end{array}$ \\
\hline & & & & & & $\begin{array}{l}\text { M: 13.0- } \\
26.4 \%\end{array}$ \\
\hline & & & & & & $\begin{array}{l}F: 13.7- \\
18.6 \%\end{array}$ \\
\hline & & & & & & $\begin{array}{l}\text { Icelandic M: } \\
1.4-6.9 \%\end{array}$ \\
\hline & & & & & & $F: 0.3-5.3 \%$ \\
\hline & & & & & & $\begin{array}{l}\text { Swedish M: } \\
2.1-3.5 \%\end{array}$ \\
\hline & & & & & & $F: 2.1-5.7 \%$ \\
\hline Iceland & 2018 & $\begin{array}{l}\text { Garmy et } \\
\text { al. } \\
\text { [22] }\end{array}$ & $\begin{array}{l}\text { Bullying in } \\
\text { School-aged } \\
\text { Children in } \\
\text { Iceland: A } \\
\text { Cross- } \\
\text { sectional } \\
\text { Study }\end{array}$ & $\begin{array}{l}\text { HBSC } \\
2013 / 2014 \text { in } \\
\text { Iceland }\end{array}$ & $\begin{array}{l}11,018 \\
\text { students } \\
(11,13 \\
\text { and } 15 \\
\text { years old) }\end{array}$ & $5.6 \%$ \\
\hline
\end{tabular}




\begin{tabular}{|c|c|c|c|c|c|c|}
\hline Country & Year & Authors & Title & Detection mode & $\begin{array}{l}\text { Sample } \\
\text { and age } \\
\text { class }\end{array}$ & $\begin{array}{l}\text { Bullying } \\
\text { Prevalence }\end{array}$ \\
\hline Australia & 2017 & $\begin{array}{l}\text { Thomas et } \\
\text { al. } \\
\text { [23] }\end{array}$ & $\begin{array}{l}\text { Prevalence } \\
\text { and correlates } \\
\text { of bullying } \\
\text { victimization } \\
\text { and } \\
\text { perpetration in } \\
\text { a nationally } \\
\text { representative } \\
\text { sample of } \\
\text { Australian } \\
\text { youth }\end{array}$ & $\begin{array}{l}\text { Single item: "In } \\
\text { the past } 12 \\
\text { months, how } \\
\text { often were you } \\
\text { bullied or } \\
\text { cyberbullied by } \\
\text { another person } \\
\text { or group of } \\
\text { young people?" }\end{array}$ & $\begin{array}{l}2,967 \\
(11-14 \\
\text { y.o. })\end{array}$ & $15.5 \%$ \\
\hline China & 2017 & $\begin{array}{l}\text { Han et al. } \\
\text { [24] }\end{array}$ & $\begin{array}{l}\text { School } \\
\text { Bullying in } \\
\text { Urban China: } \\
\text { Prevalence } \\
\text { and } \\
\text { Correlation } \\
\text { with School } \\
\text { Climate }\end{array}$ & $\begin{array}{l}\text { Ten items on } \\
\text { physical, verbal } \\
\text { bullying and } \\
\text { observers } \\
\text { phenomena }\end{array}$ & $\begin{array}{l}1,020 \\
\text { middle } \\
\text { school } \\
\text { students }\end{array}$ & $\begin{array}{l}\text { Victims: } \\
26.10 \% \\
\\
\text { Observers: } \\
28.90 \% \\
\text { (aggregated } \\
\text { data) }\end{array}$ \\
\hline $\begin{array}{l}\text { United } \\
\text { Kingdom }\end{array}$ & 2017 & $\begin{array}{l}\text { Muijs et al. } \\
\text { [25] }\end{array}$ & $\begin{array}{l}\text { Can schools } \\
\text { reduce } \\
\text { bullying? The } \\
\text { relationship } \\
\text { between } \\
\text { school } \\
\text { characteristics } \\
\text { and the } \\
\text { prevalence of } \\
\text { bullying } \\
\text { behaviors }\end{array}$ & $\begin{array}{l}\text { For students: } \\
\text { The Olweus } \\
\text { Bully-Victim } \\
\text { Questionnaire } \\
\text { (OBVQ). For } \\
\text { teachers: } 65 \\
\text { items- } \\
\text { questionnaire } \\
\text { based on } \\
\text { Kyriakides } \\
\text { (2014) scales }\end{array}$ & $\begin{array}{l}\text { Survey } \\
\text { conducted } \\
\text { in } 35 \\
\text { primary } \\
\text { schools } \\
\text { (1,411 last } \\
\text { year's } \\
\text { students } \\
\text { and their } \\
68 \\
\text { teachers) }\end{array}$ & $\begin{array}{l}\text { Victims: } \\
21 \% \\
\text { Actors: } 11 \%\end{array}$ \\
\hline $\begin{array}{l}\text { United } \\
\text { Kingdom }\end{array}$ & 2017 & $\begin{array}{l}\text { Bevilacqua } \\
\text { et al. } \\
\text { [26] }\end{array}$ & $\begin{array}{l}\text { The role of } \\
\text { family and } \\
\text { school-level } \\
\text { factors } \\
\text { in bullying and } \\
\text { cyberbullying: } \\
\text { a cross } \\
\text { sectional } \\
\text { study }\end{array}$ & $\begin{array}{l}\text { Gatehouse } \\
\text { Bullying Scale } \\
\text { (12 items) }\end{array}$ & $\begin{array}{l}6,667 \\
\text { students } \\
\text { from } 40 \\
\text { middle } \\
\text { schools }\end{array}$ & $\begin{array}{l}\text { Male: } \\
9.99 \% \\
\text { Female: } \\
13.61 \%\end{array}$ \\
\hline $\begin{array}{l}\text { USA } \\
\text { (Maryland) }\end{array}$ & 2017 & $\begin{array}{l}\text { Waarsdorp } \\
\text { et al. } \\
\text { [27] }\end{array}$ & $\begin{array}{l}\text { Ten-Year } \\
\text { Trends in } \\
\text { Bullying and } \\
\text { Related } \\
\text { Attitudes } \\
\text { Among 4th- to } \\
\text { 12th-Graders }\end{array}$ & $\begin{array}{l}10 \text { years } \\
\text { survey; } \\
\text { anonymous } \\
\text { and } 13 \text { items } \\
\text { questionnaire }\end{array}$ & $\begin{array}{l}246,306 \\
\text { students } \\
\text { in } 109 \\
\text { schools of } \\
\text { Maryland }\end{array}$ & $\begin{array}{l}28.5 \% \text { in } \\
2005 \\
13.4 \% \text { in } \\
2014\end{array}$ \\
\hline
\end{tabular}




\begin{tabular}{|c|c|c|c|c|c|c|}
\hline Country & Year & Authors & Title & Detection mode & $\begin{array}{l}\text { Sample } \\
\text { and age } \\
\text { class }\end{array}$ & $\begin{array}{l}\text { Bullying } \\
\text { Prevalence }\end{array}$ \\
\hline Vietnam & 2017 & $\begin{array}{l}\text { Le et al. } \\
\text { [28] }\end{array}$ & $\begin{array}{l}\text { Temporal } \\
\text { patterns and } \\
\text { predictors of } \\
\text { bullying roles } \\
\text { among } \\
\text { adolescents in } \\
\text { Vietnam: a } \\
\text { school-based } \\
\text { cohort study }\end{array}$ & $\begin{array}{l}\text { Two } \\
\text { anonymous } \\
\text { questionnaires; } \\
\text { single item: } \\
\text { "How } \\
\text { often have you } \\
\text { been bullied in } \\
\text { any way during } \\
\text { the last six } \\
\text { months?" }\end{array}$ & $\begin{array}{l}1,424 \\
\text { middle } \\
\text { and high } \\
\text { school } \\
\text { students }\end{array}$ & $\begin{array}{l}48.3 \% \text { : not } \\
\text { involved at } \\
\text { all; } 22.7 \% \\
\text { victims } \\
\text { only; } 6.9 \% \\
\text { bullies only; } \\
22 \% \text { bully- } \\
\text { victims. } \\
\\
\text { After six } \\
\text { months: } \\
62.1 \% \text { not } \\
\text { involved; } \\
17.6 \% \\
\text { victims } \\
\text { only; } 4.7 \% \\
\text { bullies only; } \\
15.5 \% \text { bully- } \\
\text { victims }\end{array}$ \\
\hline Spain & 2016 & $\begin{array}{l}\text { Sanchez- } \\
\text { Quelia et } \\
\text { al. } \\
\text { [29] }\end{array}$ & $\begin{array}{l}\text { Trend analysis } \\
\text { of bullying } \\
\text { victimization } \\
\text { prevalence in } \\
\text { Spanish } \\
\text { adolescent } \\
\text { youth at } \\
\text { school }\end{array}$ & $\begin{array}{l}\text { Based on HBSC } \\
2014 \text { in Spain }\end{array}$ & $\begin{array}{l}15,728 \\
(11-12 \\
\text { y.o. })\end{array}$ & $\begin{array}{l}5.5 \% \\
\text { (reported) } \\
23.6 \% \\
\text { (observed) }\end{array}$ \\
\hline U.S.A. & 2015 & $\begin{array}{l}\text { Huang et } \\
\text { al. } \\
{[30]}\end{array}$ & $\begin{array}{l}\text { The impact of } \\
\text { definition and } \\
\text { question order } \\
\text { on the } \\
\text { prevalence of } \\
\text { bullying } \\
\text { victimization } \\
\text { using student } \\
\text { self-reports }\end{array}$ & $\begin{array}{l}\text { Anonymous, } \\
\text { online, } 100 \\
\text { items-survey }\end{array}$ & $\begin{array}{l}17,301 \\
\text { students } \\
\text { attending } \\
119 \text { high } \\
\text { schools }\end{array}$ & $\begin{array}{l}\begin{array}{l}\text { Bullying } \\
\text { (overall): }\end{array} \\
9.84 \% \text { Vs } \\
13.53 \% \\
\text { cases Vs } \\
\text { controls }\end{array}$ \\
\hline Italy & 2014 & $\begin{array}{l}\text { National } \\
\text { survey } \\
\text { [31] }\end{array}$ & $\begin{array}{l}\text { Health } \\
\text { Behaviour in } \\
\text { School-aged } \\
\text { Children }\end{array}$ & $\begin{array}{l}\text { A single item } \\
\text { within a } \\
\text { broader } \\
\text { nationwide } \\
\text { questionnaire, } \\
\text { mainly focused } \\
\text { on habits and } \\
\text { lifestyles }\end{array}$ & $\begin{array}{l}4,072 \\
(11-15 \\
\text { y.o. })\end{array}$ & $14 \%$ \\
\hline
\end{tabular}




\begin{tabular}{|c|c|c|c|c|c|c|}
\hline Country & Year & Authors & Title & Detection mode & $\begin{array}{l}\text { Sample } \\
\text { and age } \\
\text { class }\end{array}$ & $\begin{array}{l}\text { Bullying } \\
\text { Prevalence }\end{array}$ \\
\hline Macedonia & 2007 & $\begin{array}{l}\text { WHO- } \\
\text { Unicef- } \\
\text { CDC } \\
\text { [32] }\end{array}$ & $\begin{array}{l}\text { Global school- } \\
\text { based student } \\
\text { health survey } \\
\text { (GSHS) }\end{array}$ & $\begin{array}{l}\text { Single item: } \\
\text { "During the } \\
\text { past } 30 \text { days, } \\
\text { on how many } \\
\text { days were you } \\
\text { bullied?" }\end{array}$ & $\begin{array}{l}2,114 \\
\text { students } \\
\text { (13-15 } \\
\text { y.o.) in } 30 \\
\text { schools }\end{array}$ & $10.1 \%$ \\
\hline Tajikistan & 2006 & $\begin{array}{l}\text { WHO- } \\
\text { Unicef- } \\
\text { CDC } \\
\text { [33] }\end{array}$ & $\begin{array}{l}\text { Global school- } \\
\text { based student } \\
\text { health survey } \\
\text { (GSHS) }\end{array}$ & $\begin{array}{l}\text { Single item: } \\
\text { "During the } \\
\text { past } 30 \text { days, } \\
\text { on how many } \\
\text { days were you } \\
\text { bullied?" }\end{array}$ & $\begin{array}{l}9,714 \\
\text { students } \\
\text { (13-15 } \\
\text { y.o.) in } 99 \\
\text { schools }\end{array}$ & $7.4 \%$ \\
\hline
\end{tabular}

\section{Discussion}

In line with some of the international studies included in this SLR, a single item prevalence of the bullying phenomenon (10.7\%) has been recorded by this survey $[21,23,32,33]$.

Moreover, similar trends in augmented prevalence of the bullying phenomenon have been reported through multiple item questionnaires both in this study $(34.8 \%)$ and other experiences $[24,25,27]$.

Probably, when facing the argument on the surface, this data could be interpreted as a former reticence of adolescents to discuss the bullying phenomena, while a latter good attitude to talk about it could be recalled, whereas the topic is more deeply discussed (i.e. using multiple basic questions).

So, on the one hand, "single item" prevalence might underestimate the bullying phenomenon (too specific question - 10.7\%), but, on the other hand, "score of 7" prevalence might overestimate the phenomenon (too sensitive tool $-52 \%$ ).

It's reasonable to think, and we used the present methods to evaluate factors associated with bullying phenomenon in the present study, that the "five question" prevalence method represents the one next to the reality at most $(34.8 \%)$.

In the national survey based on the "health behavior in school-aged children - HBSC" questionnaire analyzed the topic throughout a single-item question and the prevalence was similar to what observed in our survey with the same method, probably largely underestimating it like reported in Spain $[21,22,29$, 31].

At the same time, where the bulling phenomena were investigated with multiple items survey, the prevalance of bullying observed was similar to what reported in Sicilian survey with "the five-question" or "the score of 7" methods [24, 25, 27, 30]. 
Furthermore, this study draws attention to some important points for reflection.

First of all, it sheds light on the usually neglected figure of the observers of bullying phenomena, that usually contributed to the perpetration of bullying phenomenon as previously stated [24]. Secondly, it reaffirms the presence of a growing trend, with regard to the children's age, proportional to the degree of risk of being involved in bullying. We have documented how the phenomena more easily develops in the third classes than the latter ones, probably suggesting the presence of dynamics which are inveterate among the older children.

Moreover, our study reaffirm the role of preadolescents students prevention and contrast of bullying with resilience and prosociality that reveal higher prevalence with all the methods used and independently from other sociodemographic factors..

Bullying, in this direction, also follows the development of other risk situations, such as the beginning of the cigarette smoking habit and the voluptuous use of alcohol, typical of the adolescent or youth ages [34-38].

Another element to take into consideration is the children's school attendance falling within the territory belonging to the "C band". Similar results were previously observed in the B.I.A.S. study, examining prevalence and characteristics of the bullying phenomenon from the teachers' point of view [39].

Specifically, affective-relational discomfort, character/natural disposition and socio-cultural context were reported by the teaching staff to be the main factors associated with bullying [39].

Similarly, in the present study we observed as a relevant risk factor for the development of dynamics favouring episodes of bullying, probably due to "disadvantaged" familial and social contexts, in students attending schools belonging to " $\mathrm{C}$ " socioeconomic index. Low socioeconomic background of families might have influenced children's involvement in bullying and victimization in several ways. Parental educational level reflects intellectual resources, general and specific knowledge, norms and values, literacy, and problem-solving skills; all aspects that could be related to child-raising behaviour and, consequently, to children's development of social skills and coping strategies. Even in this case, bullying does not present a dissimilar trend when related to other indicators and / or effects of social discomfort among adolescents $[40,41]$.

The B.I.A.S. study also gave the opportunity to the adolescents to freely express through an anonymous online questionnaire, avoiding a selection bias of victims or of bullies [42]. Moreover, the bullying phenomena were analyzed using three different methods (single question; five questions; score of seven) which tried to estimate this social problem more accurately.

Moreover, our findings highlighted no significant differences between gender, nor between Italian and foreign students, although it has not been possible to clarify this last aspect, given the imbalance between the two sample sizes. 
In addition, our study allows confirming the initial hypotheses of the B.I.A.S. working group regarding the analysis of the bullying phenomenon, which could fluctuate according to the used method. In particular, what emerged is how the use of a single item in the detection of the prevalence of bullying tends to underestimate the extent of the phenomenon, while, globally considering the answers provided for each area of investigation, the values found seem to describe class dynamics more faithfully.

Specifically, a more sensitive method of analysis addresses prevalence values up to 5 times higher than those that prefer greater specificity, such as the ones built on a single item. Similarly, protective and preventive attitudes towards bullying and the key role played by observers also emerged with greater force. In this direction, similar differences can be found in an external consultation, even in surveys carried out in other areas of the globe. If, among the studies selected in this review, we separately consider the studies that exploit a single question to detect the prevalence of bullying and those that rely instead on a structured questionnaire, we note that the former gave a prevalence datum of around $10 \%$ globally. This threshold (of about 18\%) instead appears decidedly more worrying (and probably more adherent to reality) when we refer to the surveys built with a battery of questions that investigates more aspects of life and the relationships of young people.

In line with some of the international studies included in this SLR, a single item prevalence of the bullying phenomenon $(10.7 \%)$ has been recorded by this survey $[21,23,32,33]$. Furthermore, similar trends of higher prevalence of the bullying phenomenon have been reported through multiple item questionnaires (and detection methods) both in this study (34.8\%) and other experiences [24, 25, 27].

Probably, when facing the argument on the surface, this data could be interpreted as a former reticence of adolescents to discuss the bullying phenomena, while a latter good attitude to talk about it could be recalled, whereas the topic is more deeply discussed (i.e. using multiple basic questions).

So, on the one hand, "single item" prevalence might underestimate the bullying phenomenon (too specific question - 10.7\%), but, on the other hand, "score of 7" prevalence might overestimate the phenomenon (too sensitive tool - $52 \%$ ). It's reasonable to think that the "five question" prevalence method represents the one next to the real phenomenon at most (34.8\%).

A previous SLR conducted by the B.I.A.S. working group tried to investigate the association between family environment and the bullying phenomenon among school-age children in order to find some determinants of interest [42]. Despite the fact that none of the included studies have made it possible to identify determinants that can directly affect a greater or lesser probability of incurring bullying among school-age children, SLR findings could suggest a connection with some determinants, such as generalized anxiety, low self-esteem, peer relationship problems, hyperactivity and social exclusion, thus providing a paint of the psychological profile of the bully and/or victim $[43,44]$.

In any case, by additionally adhering to institutional data, which instead refer to the values found by this working group, it is evident that bullying in Italy still represents a phenomenon of wide scope, 
characterized by territorial peculiarities, with a higher frequency than what it reported in neighbouring countries or in areas with similar socio-demographic characteristics.

As reported in the present SLR, only few studies $(n=13)$ worldwide accurately analyzed the prevalence of bullying in the last decade despite it being considered an important public health problem universally.

The present study contributed to accurate evaluation of the real prevalence of bullying in school-aged children in one of the most populated Italian cities. The collection of data in other prevalence studies (such as during the "health behavior in school-aged children" study) was limited to one or two nonspecific questions and did not analyze the real impact of the phenomenon. The encouraging results obtained in a more accurate evaluation of the bullying prevalence and in the definition of factors associated with higher bullying episodes could help public health authorities in organizing dedicated interventions in a school context $[20,39]$. The main limitation of the BIAS study is the small but still representative number of the participants.

Using the same methods, further analysis could be conducted within the national and/or international context, in order to increase the representativeness and to evaluate the reproducibility of the present experience.

\section{Conclusions}

The findings provided by this study suggest that, even if we aggregate the results coming from different areas of the globe, it remains difficult to obtain univocal data that clarifies the real extent of the bullying phenomenon. The difficult comparability is given by the heterogeneity of the detection methods, of the sample numbers and, not least, of the social, economic and cultural characteristics that permeate the environments in which the interpersonal relationships of children intertwine.

Nevertheless, investigating the different prevalence of perceived bullying phenomena in school environments all over the globe is a necessary starting point to introduce tailored corrective actions of Public Health, in order to improve the psychosocial well-being of the adolescents and to promote healthy social relationships between them, during such a critical phase of their inner evolutionary growth.

\section{Abbreviations}

BIAS: Bullying In Sicilian Schools; SLR: Systematic Literature Review; SEl: Socio Economic Index

\section{Declarations}

\section{Ethics approval and consent to participate}


The informed consent was collected and signed by parents of each student that participated to the survey.

The present study obtained the approval of the Palermo Ethical Committee 1 of the University Hospital of Palermo in the $5^{\text {th }}$ session of 2018.

\section{Consent for publication}

All the authors read the final versione of the manuscript and declare their consent to publish it in the present form

\section{Availability of data and materials}

Data and materials collected are available on reasoned request to the Authors.

\section{Competing interests}

The authors declare no conflict of interest.

\section{Funding}

This research received no external funding.

\section{Author Contributions}

Conceptualization, C.C., G.V., C.M., S.E.B., E.A. M.G. and V.R..; methodology, R.G., P.S., F.V. and A.C..; software, F.S. C.S. and C.V.; validation, C.C., W.M., F.S., G.V. and V.R.; formal analysis, C.C., W.M., F.S., G.V. and V.R..; resources, E.A., M.G., R.G. and P.F.; data curation, C.C., A.C. and F.V..; writing-original draft preparation, F.S., G.V., C.M., S.E.B., C.S. and C.V.; writing-review and editing, C.C., W.M., F.V., A.C. and V.R.; supervision, E.A., M.G., R.G., P.S.; project administration, A.C. and F.V. All authors have read and agreed to the published version of the manuscript.

\section{Acknowledgments}

The authors are fully indebted with all the school directors and head teachers of schools involved and with the public health physicians operating at the LHA of Palermo for their support during the BIAS experience

\section{References}

1. Hong J, Espelage D. A review of research on bullying and peer victimization in school: An ecological system analysis. Aggress Violent Beh. 2012;17(4):311-22.

2. Hall WJ, Chapman MV. The Role of the School Context in Implementing a Statewide Anti-Bullying Policy and Protecting Students. Educ Policy (Los Altos Calif). 201832 (4): 507-539. 
3. Silva JLD, Oliveira WA, Carlos DM, Lizzi EADS, Rosário R, Silva MAI. Intervention in social skills and bullying. Rev Bras Enferm. 2018;71(3):1085-109.

4. Eleni P. School Bullying: The Phenomenon, the Prevention and the Intervention. Procedia - Social Behavioral Sciences. 2014;152:268-71.

5. Olweus D. Bullying at School: What we know and what we can do. United Kingdom Blackwell Publishing; 1993.

6. Olweus D. Peer abuse or bullying in school: Basic facts and a school-based intervention program. Prospects. 1995;25:133-9.

7. Olweus D. Sweden. In the nature of school bullying: A cross-national perspective. London Routledg. 1999.

8. Ferrara P, Franceschini G, Villani A, Corsello G. Physical, psychological and social impact of school violence on children. Ital J Pediatr. 2019 Jun 27;45(1):76.

9. Ttofi M, Farrington D. Reintegrative Shaming Theory, moral emotions and bullying. Aggress Behav. 2008;34(4):352-68.

10. Ttofi M, Farrington D, Lösel F, Loeber R. The predictive efficiency of school bullying versus later offending: A systematic/meta-analytic review of Iongitudinal studies. Crim Behav Ment Health. 2011;21(2):80-9.

11. Ttofi M, Farrington D. Risk and protective factors, longitudinal research, and bullying prevention. New Dir Youth Dev. 2012 (133):85-98.

12. Ferrara P, lanniello F, Villani A, Corsello G. Cyberbullying a modern form of bullying: let's talk about this health and social problem. Ital J Pediatr. 2018 Jan;17(1):14. 44(.

13. Malamut S, Berg Y, Lansu T, Cillessen A. Dyadic nominations of bullying: Comparing types of bullies and their victims. Aggress Behav. 2020;46(3):232-43.

14. Alonso C, Romero E. Aggressors and Victims in Bullying and Cyberbullying: A Study of Personality Profiles using the Five-Factor Model. Span J Psychol. 2017;4:20:E76.

15. Zaborskis A, llionsky G, Tesler R, Heinz A. The Association Between Cyberbullying, School Bullying, and Suicidality Among Adolescents. Crisis. 2019;40(2):100-14.

16. Sorrentino A, Baldry A, Farrington D. The Efficacy of the Tabby Improved Prevention and Intervention Program in Reducing Cyberbullying and Cybervictimization among Students. Int J Environ Res Public Health. 2018;15(11):2536.

17. ISTAT. Report: II bullismo in Italia: comportamenti offensivi e violenti tra i giovanissimi. 2014. https://www.istat.it/it/files/2015/12/Bullismo.pdf. Accessed 03 Sep 2021.

18. Report nazionale dati HBSC Italia. 2014. http://www.hbsc.unito.it/it/images/pdf/hbsc/report_nazionale_2014.comp.pdf. Accessed 03 Sep 2021.

19. Marotta C, Restivo V, Arcidiacono E, et al. The BIAS (bullying in SiciliAn school) pilot study: investigating the prevalence of bullying in school of Palermo city. A protocol study. 
EuroMediterranean Biomed J. 2017;2(44):205-8.

20. Costantino C, Casuccio A, Marotta C, Bono S, Ventura G, Mazzucco W, Vitale F, Restivo V. Effects of an intervention to prevent the bullying in first-grade secondary schools of Palermo, Italy: the BIAS study. Ital J Pediatr. 2019;27(1):65. 45(.

21. Arnarsson A, Nygren J, Nyholm M, Torsheim T, Augustine L, Bjereld Y, Markkanen I, Schnohr C, Rasmussen M, Nielsen L, Bendtsen P. Cyberbullying and traditional bullying among Nordic adolescents and their impact on life satisfaction. Scand J Public Health. 2020;48(5):502-10.

22. Garmy P, Vilhjálmsson R, Kristjánsdóttir G. Bullying in School-aged Children in Iceland: A Crosssectional Study. J Pediatr Nurs. 2018;38:e30-4.

23. Thomas H, Connor J, Lawrence D, Hafekost J, Zubrick S, Scott J. Prevalence and correlates of bullying victimisation and perpetration in a nationally representative sample of Australian youth. Aust N Z J Psychiatry. 2017;51(9):909-20.

24. Han Z, Zhang G, Zhang H. School Bullying in Urban China: Prevalence and Correlation with School Climate. Int J Environ Res Public Health. 2017;14(10):1116.

25. Muijs D. Can schools reduce bullying? The relationship between school characteristics and the prevalence of bullying behaviours. Br J Educ Psychol. 2017;87(2):255-72.

26. Bevilacqua L, Shackleton N, Hale D, Allen E, Bond L, Christie D, et al. The role of family and schoollevel factors in bullying and cyberbullying: a cross-sectional study. BMC Pediatr. 2017;11(1):160. 17(.

27. Waasdorp T, Pas E, Zablotsky B, Bradshaw C. Ten-Year Trends in Bullying and Related Attitudes Among 4th- to 12th-Graders. Pediatrics. 2017;139(6):e20162615.

28. Le H, Dunne M, Campbell M, Gatton M, Nguyen H, Tran N. Temporal patterns and predictors of bullying roles among adolescents in Vietnam: a school-based cohort study. Psychol Health Med. 2017;22(sup1):107-21.

29. Sánchez-Queija I, García-Moya I, Moreno C. Trend Analysis of Bullying Victimization Prevalence in Spanish Adolescent Youth at School. J Sch Health. 2017;87(6):457-64.

30. Huang F, Cornell D. The impact of definition and question order on the prevalence of bullying victimization using student self-reports. Psychol Assess. 2015;27(4):1484-93.

31. Epicentro.iss.it. Indagine 2014 - Hbsc. 2014. https://www.epicentro.iss.it/hbsc/indagine-2014. Accessed 03 Sep 2021.

32. Who.int. Global school-based students health survey. 2007. https://www.who.int/ncds/surveillance/gshs/macedonia/en/. Accessed 03 Sep 2021.

33. Who.int. Global school-based students health survey. 2006. https://www.who.int/ncds/surveillance/gshs/tajikistan/en/. Accessed 03 Sep 2021.

34. Williams G, Battista $\mathrm{K}$, deGroh $\mathrm{M}$, Jiang $\mathrm{Y}$, Morrison $\mathrm{H}$, Leatherdale S. Longitudinal associations between bullying and alcohol use and binge drinking among grade 9 and 10 students in the COMPASS study. Can J Public Health. 2020;111(6):1024-32. 
35. Maniglio R. Bullying and Other Forms of Peer Victimization in Adolescence and Alcohol Use. Trauma Violence Abuse. 2017;18(4):457-73.

36. Azagba S. School bullying and susceptibility to smoking among never-tried cigarette smoking students. Prev Med. 2016;85:69-73.

37. Vieno A, Gini G, Santinello M. Different Forms of Bullying and Their Association to Smoking and Drinking Behavior in Italian Adolescents. J Sch Health. 2011;81(7):393-9.

38. Cerame G, Meli V, Vitale F, Firenze A, Viviano E, Mazzucco W, Romano N. A study to evaluate the lifestyle of medical students in Palermo (Italy). Igiene e Sanità Pubblica. 2008;64:473-88.

39. Costantino C, Ventura G, Marotta C, et al. Prevalence of the bullying phenomenon in a schools sample of Palermo, Sicily: a pre-post intervention observational study among teachers. Acta Biomed. 2018;8(3):443-51. 89(.

40. Tippett N, Wolke D. Socioeconomic Status and Bullying: A Meta-Analysis. Am J Public Health. 2014;104(6):e48-59.

41. Jain S, Cohen A, Paglisotti T, Subramanyam M, Chopel A, Miller E. School climate and physical adolescent relationship abuse: Differences by sex, socioeconomic status, and bullying. J Adolesc. 2018;66:71-82.

42. Costantino C, Restivo V, Scarpitta F, et al. Association between family environment and the bullying phenomenon among school-age children: A systematic review. EuroMediterranean Biomed J. 2019;14(41):172-5.

43. Jansen PW, Verlinden M, Dommisse-van Berkel A, et al. Prevalence of bullying and victimization among children in early elementary school: do family and school neighbourhood socioeconomic status matter? BMC Public Health. 2012;2:12:494.

44. Bond L, Carlin JB, Thomas L, Rubin K, Patton G. Does bullying cause emotional problems? A prospective study of young teenagers. BMJ. 2001;323:480-4.

\section{Figures}


No. 1412 records

identified through

PubMed/MEDLINE, SCOPUS,

EMBASE and ISI Web of Science

database searching using the

string

No. 1256 after removal or duplicates
No. 156 issues already

present in at least another

search engine or not in

English language

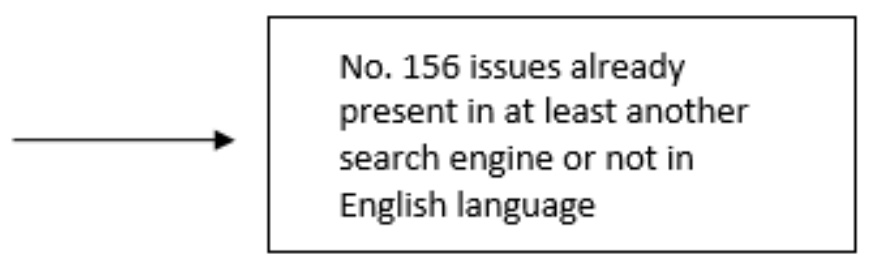

1242 removed due to exclusion criteria.

No.1 added and No.2 excluded after a collegial discussion

\section{Figure 1}

Flow systematic literature review diagram of the manuscripts reporting the prevalence of the bullying phenomenon. 